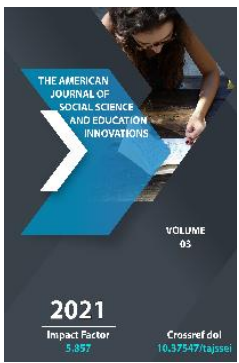

\title{
Innovation And Social Development
}

\author{
Akbar Saitkasimov \\ Doctor Of Philosophical Sciences (DSc), Assistant Professor Of The Chair "Philosophy, Upbringing \\ And Law Education" Of Jizzakh State Pedagogical Institute, Uzbekistan, Jizzakh
}

Journal Website:

http://usajournalshub.c

om/index,php/tajssei

Copyright: Original content from this work may be used under the terms of the creative commons attributes 4.0 licence.

\section{ABSTRACT}

In the context of building a civil society, the scientific development of the problem of innovative development of all spheres of social life and ensuring the modern development of society through this process is the actual essence. In today's period of socio-economic development, the concept of innovation is widely applied, its role in the development of society is growing and becoming an important value in social life. This is due to the fact that today, as a result of rapidly accelerating global socio-economic changes and the need to apply innovations, society and humanity are required to have a high level of innovation in all spheres of society. Innovation plays an important role in the development of the country as one of the key factors in ensuring progressive changes in social life, renewal and modernization of society.

\section{KEYWORDS}

Society, human, innovation, renewal, modernization, science, cultural being, intellect, progress, globalization, competition, innovative thinking, innovative activism, human interest, necessity, economy, technology, social, new idea, prosperity. 
At the current stage of development, the world is experiencing trends of modernization and innovative development. In the 21st century, innovation processes have emerged as the main driving force of social and economic development. In the context of globalization of the world economy, increasing competition, the flow and scale of innovations is expanding, which has a significant impact on the interests and needs of society and human. In international practice, the development of social life on an innovative basis is one of the main criteria for building civil society, and this process is closely linked with the level of their innovative potential and capabilities. There is a need to further improve the process of innovative development of countries with promising development programs, which are constantly introducing scientific and technological innovations in all areas, in defining their sustainable development strategies and ensuring the priority of human welfare. Prospective programs of modernization of public life, application of innovations in practice, systematic implementation of important reforms in social life are a necessary factor in improving human well-being. As noted by President Sh. Mirziyoyev, "Today we are moving on the path of innovative development aimed at radical renewal of all spheres of life of the state and society. This is not in vain, of course. Because in today's fast-paced world, who will win? A state based on new thinking, new ideas and innovations will win." (Mirziyoyev Sh., 2017.).

Society and human organize an innovative process based on creative activity in order to fully meet their needs. Innovative activity gains social status because it stems from human needs and interests. Social status-based activity, the phenomenon of adaptation to the dynamics of change, are the means of existence of the cultural being that is the basis of society. Hence, the innovative activity arising from this process is an attribute of social development. Consciousness, including innovative thinking, plays an important role in understanding the needs and interests of society and performs a gneological function in the cultural being that is the basis of society. The methodological ideas put forward in the spheres of social life, that is, the laws related to the innovation of economic, social, political and cultural systems, that is, to give them a new look, innovate and modernize, participate as coordinating rules in this system of epistemological basis. Innovative processes in the social space are the result of human creative initiatives. They are manifested in the form of developments, projects and programs in the innovation of spheres of social life. The results of innovative creative activity serve as a source and means of cultural existence and its subjects, which are the basis of society.

The implementation and assimilation of the results of innovative creative activity is the process of consumption. This substantial element is manifested in the form of implementation and use of projects in the process of innovation of spheres, systems and infrastructure of social life. This element is a way of existence of society as an important stage of social activity. 


\section{MATERIALS AND METHODS}

The study of the characteristics of innovation as a whole in the social sphere today is becoming the task of both the economic and natural sciences, as well as the social and humanitarian sciences. In particular, in the system of philosophical sciences, along with such disciplines as sociology, political science, cultural studies, the role of innovation in society and human life is studied, which allows the socio-philosophical analysis of innovation processes.

The problem of innovation in social development has been studied in a number of works by foreign scholars. Among them, it is possible to note scholars such as J. Schumpeter, F. Malerba, M. Croco, R. Delbrj, J. Bessant, J. Zaltman, P. Draker, M. Bagomedov, A. Musaeva, I. Vodyanenko and L. Galaktionova. Also, among foreign scientists, R. Nelson and A. Johnson considered innovation as a system.

In recent years, a number of studies have been conducted in our country, covering a certain level of problems in the development of social life, renewal and modernization of society, such as S. Shermuhammedov, A. Saidov, J. Yahshilikov, B. Turaev, N. Juraev, K. Nazarov, S. Otamurodov, S. Karimov, A. Kholbekov, R. Jumaev, T. Juraev, I. Ergashev, M. Kirgizbaev, A. Erkaev and M. Bekmurodov are among them. Our scientists such as R. Ubaydullaeva, Hk. Abdusattorova have researched the importance of the innovation factor in the new period of social development.

\section{DISCUSSION AND RESULTS}

Explaining innovation processes on a philosophical basis, approaching it from a scientific and philosophical point of view is one of the important prospects of social philosophy. The philosophical interpretation of innovative processes provides the basis for its view as an important driving force in the relationship between nature, society and human. In social philosophy, the human factor in society, its role in social relations are one of the important issues. Progressive innovations and changes in social life play an important role in ensuring these relations on a sustainable basis.

Innovation and innovative activity is organized on the basis of socio-economic interests and needs of the subjects of social life, expands the scope of infrastructure in all spheres of society, creates creative values in people's minds through new thinking, develops material, social, political, spiritual, material and acquires a scientific and philosophical significance as a social phenomenon that ensures the harmony of spiritual life and, ultimately, the well-being of human and society.

One of the main criteria that plays an important role in social development is that innovation is a process that is able to change a person's lifestyle and content of life in a positive, modern way, progressive in terms of space and time. According to the researchers, "Philosophical observation of the theme of innovation and innovative development, its scientific generalization serves to express its appearance, role and importance in human and social life. This need is further explained by the fact that the explanation of innovation reinforces the emergence of different approaches in revealing its functions in social life. (Ardakshin I., 2017. p.45). 
In this context, research to increase opportunities for innovation in society plays an important role. These innovative researches serve as a unique tool for society and human development. As a result, human becomes a key participant in the changes and innovations that make up the criterion of social development. At the same time, there is a need for people to act on the basis of more innovative cooperation than ever before with government agencies, public institutions, economic structures, which will ultimately ensure social stability in society. Social stability is the first condition for the development of society and lays the groundwork for positive and innovative change in the spheres of social life. In this context, according to academician S. Shermuhammedov, "the principles of sociopolitical stability are to ensure social justice, economic and political development". (Shermuhammedov S., 2002. p.24).

"Innovation" occurs in all spheres of society, in all aspects of human life. Based on the results, volume, and practices of scientific research, innovations make a tremendous contribution to the socio-economic development of a society. Innovations, on the other hand, are manifested in the sequence of new knowledge, the creation of innovations, their implementation and expression of the level of efficiency. This, in the new conditions, serves to create modern conditions for human life. "The well-being of citizens in any country depends on the innovative development of that society", - said the scientists. (Shindina, N., 2017). Indeed, in developed countries, 90 percent of GDP is accounted for by new knowledge and innovative technologies.

The concept of innovation was first introduced to science by the Austrian scientist Josef
Schumpeter. He wrote Theory of Economic Development in 1911 and raised the issue of "new developments". By the 30 s of the last century, the scientist began to use the term "innovation" for the sphere of new production, vehicles, industrial organization, development of market infrastructure, production of consumer goods.

The word "innovation" is based on the word "novation". Such words entered the Uzbek dictionary from foreign languages. For example, the English word "innovation" in the Russian dictionaries interpreted as “нововведение”, “новаторство”. According to the Russian interpretation, the word is translated and interpreted in Uzbek in the sense of "new introduction", "new method", "introduced novation". The Uzbek dictionary defines the term "innovation" as the introduction of new types (generations) of machinery and technology in the economy. (Explanatory Dictionary of the Uzbek language. 2006. p.212).

So, "novation" is a new development, prepared for innovation, production or economic infrastructure, which did not exist before, and has not yet been created in the world of science or scientific discoveries. Novation is a state of preparedness of a novelty, but it has not yet been introduced into the national economy, into an object. Innovation becomes an innovation in the process of introduction into a sector of the economy.

In the study of innovation theory, specific concepts such as "innovation", "novation", "application of novation", "active innovation", "innovative thinking", "innovative potential", 
"innovative processes", "innovative activity" add complement to its essence.

The category of "novation" means the objective and subjective factors of human activity in society, the creation of a novelty or scientific justification.

There are the following types of "novation" related to the creator of the renewals:

- Individual, the product of human activity is not completely unique to society, it has a subjective, individual and psychological nature;

- Local or group, the product of human creative activity belongs only to a certain group of people or certain regions;

- Regional, in which the novations that are the product of creativity belong to the region or country;

- International, namely innovations will be recognized by the international community.

The category "Innovation" is defined by scientists in different contexts, interpretations and comments. The given ideas reveal some features of innovations. Some scientists say that "innovation is the whole process from the emergence of an idea to its finished product and its entry into market consumption". (Cooke, I., Mayers, p.1996). In this definition, innovation is seen only as a concept related to production, the essence of which is revealed in a narrow sense.

Other researchers explain that "Innovation is a separate form of theory and practice, a system of actions aimed at improving the characteristics of the social, economic, cultural object". (Saatova L., 2018. p.132). The quote acknowledges that innovation is a process related to all spheres of society, and that it is a progressive phenomenon that serves the wellbeing of human and society, that is, contributes to social development and has a positive impact on cultural processes.

Indeed, the creation and introduction of innovations in society creates innovative activity. Innovation is a very multifaceted process, which creates a system of "human scientific and process - innovation". Through this system, innovations are created and implemented. According to the researchers, "the systemic nature of innovation processes is also associated with its goal-orientation, so all components of innovation processes determine the balance of interests and the overall dynamics of development". (Vasileva E., 2007. p.5).

Also, as a result of this process, new promising values are emerging in society, its sustainable development is ensured, and the features of innovative development of all systems of social life are identified. According to J. Yahshilikov, "Innovation is the introduction of novations in all spheres of society, that means systematic, integrated, designs a new system of activities in a particular practice, this activity is completely renewed with new qualitative results in material and spiritual production" (Yahshilikov, J. 2018. p.550-551).

Innovative activity is the completion of scientific research and development, the creation of scientific and technical products designed to market improved products, new and effective technological processes used in 
practice, as well as additional measures to be taken as needed.

Innovations are applied in all spheres of public life and serve its development. It involves the following process, depending on its content, scope, and purpose:

- Is applied fully or partly in intellectual activity with appropriate results;

- Promotes the creation of legally relevant scientific developments and products;

- Produces quality goods and services that meet relevant international standards;

- Efficiency is achieved in the production process of products and services.

Thus, innovation processes incorporate such tools that scientific discoveries eventually become socially significant innovations and acquire a specific essence. The process of introducing innovations is a product of innovations, and innovation processes constitute their commonality.

It consists of three stages: scientific discoveries, development of ideas and implementation of innovations. Thus, innovative processes include the process of applying scientific ideas to practice in the socioeconomic sphere as changes from the initial stage of creation. The transformation of ideas into innovations and the emergence of management practices in this process is called innovative activity.

When talking about innovation processes and its nature, it is necessary to discuss its effectiveness. The effect of innovation is related to the current state of production of society, the spiritual image of the nation, its enlightenment and intellectual level, moral qualities, physical and mental abilities. In creating and introducing innovations in society, it is necessary to choose innovations that have a high impact on human and social development and the well-being of the population. This creates social values that are important for the future and future of society.

According to academician I. Muminov, "Our interest in the traditions and nature of social life, the nature of traditions in the creation of innovations is growing as a matter of course". (Muminov, I. 1977. p.7). Hence, the progressive values, needs and efforts to create various innovations in society related to the development of all its spheres in relation to the point of view of space and time will continue.

The scale of innovation is associated with the development of education, science, culture and enlightenment. Innovative processes are associated with large-scale positive changes in knowledge, consciousness, thinking, psychology, spiritual values of members of society. Modern reforms in education and science require the education of today's innovative human, his radical renewal of society as a highly thinking, strong talent for innovation, preparing him to fight for its future.

The first stage of innovative development of social life consists of the first substantial element - the subjects, the second substantial element - the needs and interests for innovative development, the third substantial element - innovative consciousness, the fourth substantial element - innovative creativity. 
The fifth substantial element of systemic innovation development is the second stage of innovative development of social life spheres, as innovative ideas, projects and programs have a specific qualitative specificity.

The sixth substantial element of the system of innovative development is innovative accounting, the implementation of the results of innovations has a specific quality, and is the third stage of innovative development of social life.

The first stage of the innovation process creates the second stage, the second stage the third stage. The third phase ensures the existence of the first phase by meeting people's needs for innovation. From this innovative process the following three specific substantial laws arise:

1) The law of substantial integrity of innovative development of spheres of social life;

2) The law of progressive circle of innovative development of spheres of social life;

3) The law of constant increase of needs for innovative development of all spheres of social life.

The law of substantial integrity of the innovative development of the spheres of social life reveals the mechanisms of the transition of quantitative and qualitative changes in innovation processes. The law of the circular cycle of innovative development of spheres of social life is the source of innovative processes. The relationship between the need for innovation and the implementation of the results of innovative creativity serves as one of the vital criteria for the innovative development of society.

\section{CONCLUSION}

The need for innovative development of all spheres of social life never stops. The law of constant increase in the need for innovative development determines the direction of innovative development based on dialectical negation in every sphere.

The influence of the human factor in society, the processes of realization of its abilities in the development of innovation is high. Human is creative, innovative subject in society. Through the innovative development of the spheres of social life, mainly human well-being and interests are realized. Without human, the processes of innovative development in social life are unimaginable, innovative activity of human serves to create innovations in society, the emergence of innovations and, ultimately, to increase human well-being.

Based on the demand and needs for social innovation today, they are classified as follows:

- Social innovations, complex and local social innovations on the coverage of social factors;

- In terms of implementation period, strategic and tactical innovations;

- Innovations in working conditions and existing social infrastructure for the formation of social orientation in organization;

- In terms of state of application, social innovations aimed at overcoming internal and external social problems; 
- According to the form of implementation, organizational and cultural social innovations;

- In terms of scope of use, one-time social innovations focused on a single object and comprehensive social innovations focused on multiple objects;

- According to the purpose, innovations aimed at updating the principle of operation and innovations aimed at the organization of new product activities.

In this sense, innovation reflects the advanced traditions of society and human development, such as their comprehensive development reflects in the formation of various social relations in society such as integral and mutually beneficial, economic, cultural, family, political relations. The realization of these quality indicators will require an innovative approach to social development, that is, we see that this process is inextricably linked with the introduction of innovations in all spheres of society.

\section{REFERENCES}

1. Мирзиёев, Ш. (2017). 'Ўзбекистон Республикаси Олий Мажлисига мурожаатнома` 22 декабрь. www.uza.uz.

2. Ардакшин, И. (2017). 'Инновации и инновационное развитие: социальнофилософский подход: //Вестник Томского государственного университета. №422. с. 45.

3. Шермухаммедов, С. (2002). 'Истиқлол қуёши'. -Тошкент: Ma'rifatMadadkor, б. 24.
4. Шиндина, Н. (2017). 'Особенности инновационного развития в современном обществе: социологический аспект`. //Научнометодический электронный журнал «Концепт». -№ 4 (апрель). -03 пл. URL: http: //е-коncept.ru. //2017// 170088. htm. ART 170088.

5. ั Ўбек тилининг изохли луғати. (2006). 2-китоб, -Тошкент: Ўзбекистон миллий энциклопедияси, б. 212.

6. Cooke, I, Mayers, P. (1996). 'Introduction to Innovation and Technology Transfer` Boston: Artech House, Inc.

7. Саатова, Л. (2018). 'Инновацион фаолият ва уни ташкил этишнинг назарий асослари`. //Иқтисодиёт ва таълим, №2, 6.132.

8. Васильева, Е. (2007). 'Закономерности процесса инноваций последней четверти XX века`. - Москва: Экономика, с. 5.

9. Яхшиликов, Ж. (2018). 'Миллий ғоя: Ўзбекистонни ривожлантириш стратегияси`. -Тошкент, Чўлпон, б. 550-551.

10. Мўминов, И. (1977). 'Избранные произведения`. Том 4. -Ташкент: Узбекистан, с. 7. 